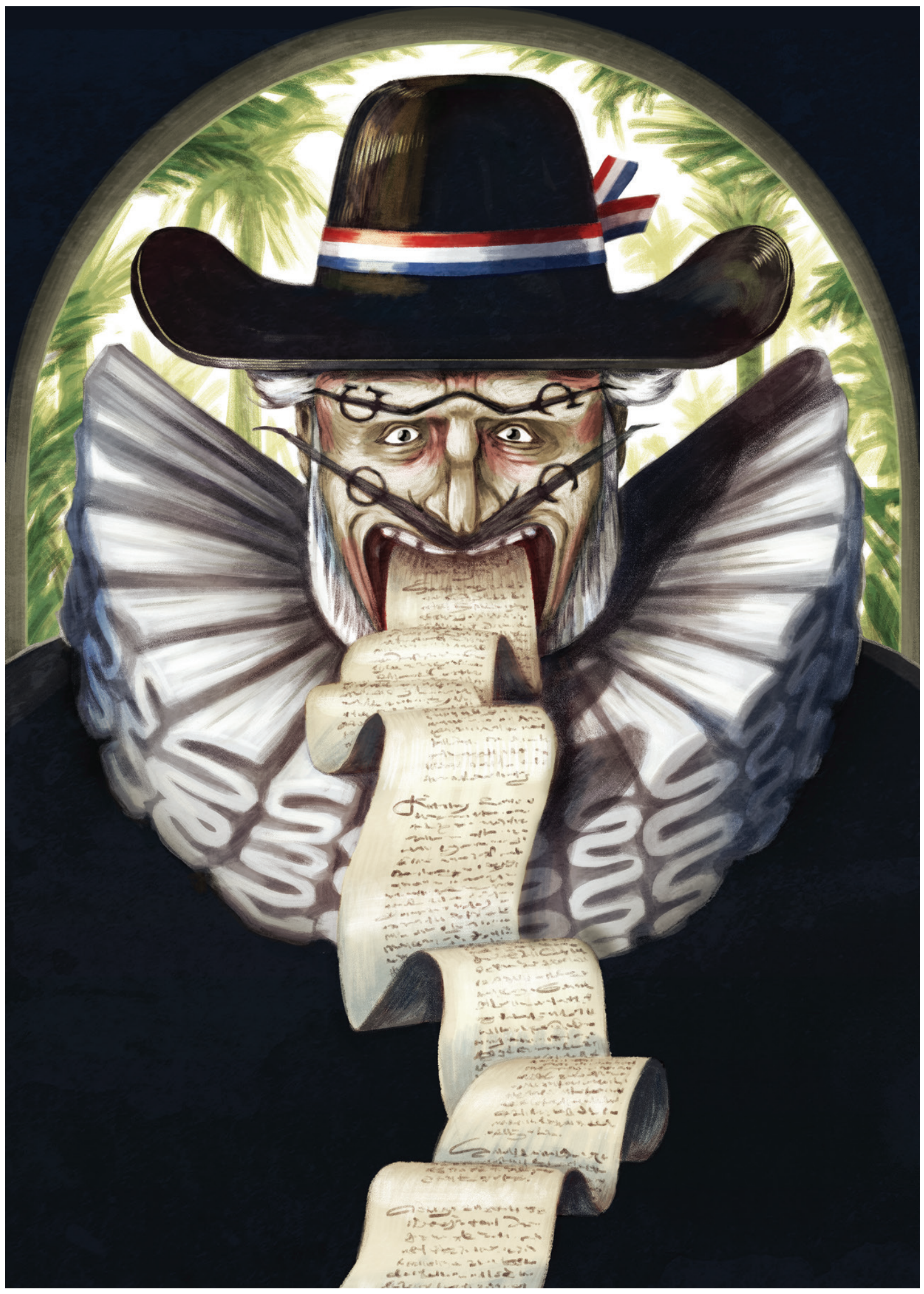




\title{
How Generations Matter
}

\section{BMGN and the Problem of Writing Histories of Colonialism}

\author{
AGUS SUWIGNYO, ALICIA SCHRIKKER AND \\ SUSAN LEGÊNE
}

In de historiografie spelen generaties een rol, en dit is zeker het geval inzake het langdurige proces van dekolonisatie. In deze forumbijdrage bespreken wij de artikelen die opeenvolgende generaties sinds 1970 over kolonialisme, imperialisme en dekolonisatie in BMGN - Low Countries Historical Review publiceerden. Deze bijdrage gaat over verschillen en continuïteiten in de onderzoekspraktijken tussen de oudere generatie historici die het kolonialisme zelf nog meemaakten, en de daaropvolgende generaties. De geschiedschrijving van het koloniale verleden is verweven met debatten over dekolonisatie; dat houdt ook het idee van 'deimperialisatie' in, oftewel het bevorderen van een geschiedschrijving waarin Europa niet in het centrum staat. Door de inhoud van de BMGN onder de loep te nemen kunnen we deze ontwikkelingen enigszins volgen, ook al figureerde de thematiek van kolonialisme, imperialisme en dekolonisatie bepaald niet prominent in de BMGN van de voorbije vijf decennia. Qua historiografie laten de artikelen echter wel degelijk veelzeggende trends zien, zoals veranderingen op het vlak van bronnenkritiek, van de internationale reikwijdte van het debat en met betrekking tot de gekozen conceptuele benaderingen. We zien bijvoorbeeld dat een toenemende belangstelling voor het koloniale verleden, ook buiten de geschiedwetenschap zelf, de perceptie heeft beïnvloed van historici ten aanzien van koloniaal geweld - zowel in diens fysieke, socio-culturele als in zijn kennistheoretische vorm. Ondanks allerlei lacunes, laat het groeiende aantal publicaties in de BMGN sinds 2006 over kolonialisme en dekolonisatie zien dat deze thematiek voor de huidige generatie historici een integraal onderdeel is geworden van de geschiedschrijving in Nederland en België. 
Generations matter in historiography, and this is certainly the case when it concerns the enduring process of decolonisation. This forum contribution discusses how different generations published about colonialism, imperialism and decolonisation in BMGN - Low Countries Historical Review since 1970. It raises questions about contrasts and continuities in research practices between the older generation of historians with first-hand experience with colonialism, and subsequent generations. Writing the history of colonialism intersects with debates about decolonisation, including what we characterise as de-imperialisation, namely decentring Europe, in history writing. Examining the content of BMGN allows us to trace this development, even though the subject of colonialism, imperialism and decolonisation did not feature prominently in BMGN over the past five decades. However, in terms of historiography, the articles do show significant trends, such as changes in source criticism, in the international scope of the historical debate, and in conceptual approaches. We observe how a growing interest in the colonial past beyond the discipline of history as such has influenced perceptions among historians of colonial violence, in its physical, socio-cultural and epistemic forms. Despite its lapses, the increasing number of articles on colonialism and decolonisation published in BMGN since 2006 show that for the current generation of historians, colonialism and decolonisation have become an integral part of history writing in the Netherlands and Belgium.

\section{Introduction}

The history of the Low Countries' colonialism, imperialism and decolonisation covers a rather broad field. It is hard to separate it from other aspects of 'Low Countries history' such as the history of science, gender, labour and warfare, and it also connects to local historiographies in Asia, Africa and the Americas, as well as the field of global history. Even if defined more narrowly, it encompasses the history of early modern trading companies - voc, WIC, MCC - and its successors such as NHM, as well as the formation of colonial states in countries such as Suriname, Curaçao, Indonesia, Congo, Rwanda and Burundi, and debates on European imperialism and global history. There are journals devoted to each of these regions, periods and themes. What then can we expect to find in fifty years of publications on colonialism, imperialism and decolonisation in BMGN - Low Countries Historical Review? Will we just find fragments of historiographic developments, or does this theme provide us with a lens through which one can consider the changing conceptions of the history of Low Countries' colonialism and imperialism that have been portrayed by the journal, its authors and readers over the past five decades? 
This contribution focuses on approaches and historical practice. How did historians who published in BMGN operate? Who did they work with? Who did they read? But also, what was not published in BMGN? Writing the history of colonialism intersects with debates about decolonisation, including what we call de-imperialisation (namely decentring Europe) in history writing. Our snapshots from BMGN will show that this is a matter of source interpretation and more: changing conceptions also relate to the then current political and societal debates and questions of background, perspectives and transnational connections among historians from the formerly colonising and colonised countries with respect to the history of the Low Countries. We end this quick scan with a discussion of the most recent publications in BMGN from an Indonesian perspective.

Snapshot

Let us start with the following case: we were pleasantly surprised to find the same letter, sent by the Dutch missionary family Van Hasselt from Papua New Guinea to the Netherlands, quoted in one of the first and last articles published in BMGN between 1970 and 2020 :

Until around 1900 slave trade existed in New Guinea, not clandestinely but publicly [...] As long as the male and female slaves were strong, it was in the best interest of the owners to treat them well, but small children, sick, weak or old slaves were killed, often with accusations that they were bewitched. ${ }^{2}$

In 1971, Steven van Randwijck took this quotation at face value in an article that discussed the relationship between Protestant missionaries and Dutch imperialism. He argued that indeed imperialism and conversion often went hand in hand, but in his view, whereas Dutch imperialists were driven by selfinterest, the missionaries acted out of interest for the population. To illustrate this, he quoted Van Hasselt's letter, thus confirming Van Hasselt's view that Christianity brought civilisation to Papua through the abolition of slavery and the protection of women and vulnerable children. ${ }^{3}$ reason to expect an improvement in the lot of the people from the establishment of our authority, even though the remnants of past abuses (restanten van vroegere misbruiken) have often had 
Fifty years later, Geertje Mak discussed the same letter to argue exactly the opposite. According to Mak, Van Hasselt consciously painted an image of Papuans and Papuan children as people who needed to be saved by missionaries: 'Missionaries' reports tended to highlight the loving care with which the children were welcomed in their households and downplayed the services and labour the children provided'. ${ }^{4}$ She further argues that the children became set apart from their community, and the cultural values with which they were raised became lost. In her view, the missionaries played a key role in Dutch colonialism. ${ }^{5}$ The interpretation of the same source by these two historians could not have been more different.

The contrast between the analysis of Van Randwijck and Mak suggests that BMGN changed its approach to colonialism over the course of fifty years: from a colonialist perspective, where historians reproduced visions from their sources, to a critical post-colonial approach that questions precisely the message the source intended to convey. This shift conforms to international developments in the field and in that sense should not surprise us. But this was not a gradual process; rather, it reflects a generational change that happened only ten years ago. Over the past ten years or so, BMGN has experienced a true explosion in the number of articles, special issues, discussion dossiers, forums and review essays on the history of colonialism, imperialism and decolonisation. In 2020 alone we counted nearly twenty contributions. This large number of colonialism-related publications in BMGN starkly contrasts with the preceding four decades, which counted barely more than one colonialism-related article per year, and surely reflects the current academic, societal and political interest in the history of colonialism in the Netherlands and Belgium. Authorship changed too, for instance in terms of gender (see in general graph 6). The 1971 snapshot was part of a themed issue (BMGN - LCHR 86:1) written by men only, whereas the authors of the 2020 special issue (BMGN 135:3/4), in which Mak's article featured, were all female. Furthermore, the journal's readership has changed considerably since it started publishing in open access and in English. In previous years, the download figures suggest that Indonesia is one of the regions where a substantial part of the journal articles is downloaded.

A closer look at the 1971 themed issue about the history of Dutch imperialism and expansion shows that in fact most contributors were critical

a tough life', Van Randwijck, 'Enkele opmerkingen over de houding der zending', 58. Translation by authors.

Historical-Anthropological Reconstruction of the Background of Children purchased by Dutch Missionaries between 1863 and 1898 in Dutch New Guinea', BMGN - LCHR 135:3/4 (2020) 29-55, 31. DOI: https://doi.org/10.18352/bmgn-lchr.10876.
5 Mak, 'Children on the Fault Lines', 33. This is a key point in the special issue as a whole in which Mak's article featured, and that she edited with Marit Monteiro and Elisabeth Wesseling, see: 'Child Separation: (Post)Colonial Policies and Practices in the Netherlands and Belgium', BMGN - LCHR 135:3/4 (2020). DOI: https://doi. org/10.18352/bmgn-lchr.10871. 
of Dutch imperialism. However, both in conceptual and empirical terms, their articles fit in a narrow frame of reference that nowadays would no longer be satisfactory. Van Randwijck's lack of source criticism may be explained by his background as Secretary-General of the Nederlandsch Zendeling Genootschap. In that respect he was still inhabiting the colonial world whose history he was evaluating. Others, such as Willem Wertheim or Jan Pluvier, did raise more critical questions which have reappeared in historical debates in BMGN to this day: they questioned the traditional Dutch exceptionalist selfperception as a non-imperialist colonial power and they explained the Dutch presence in terms of colonial enclaves which had limited contact with and little understanding of the Indonesian world around them, even if the Dutch at the time thought otherwise. They also highlighted the strong European character of Dutch colonial society. ${ }^{6}$ These are all subjects that returned in fora and themed issues in the 2010s. ${ }^{7}$ The major differences in the more recent contributions on such themes are the more explicit source-critical approaches, comparative insights and stronger commitment to theory.

\section{Generations}

An examination of the authorship of the 1971 issue provides yet another snapshot: that of a generation of historians whose lives and careers had been entangled with the colonial world. Some served as officials in Indonesia, others were raised in the colonial enclaves they later wrote about. ${ }^{8}$ Only one of them was Indonesian, The Siauw Giap, who by then had settled as an academic in the Netherlands. The authors cited Indonesian historians such as Sartono Kartodirdjo and Indonesian sources such as the work of Noto Suroto. ${ }^{9}$ The personal connection with the former colonial world of Indonesia characterised this generation of historians and for that reason they stood close to Indonesian academia as well.

After 1971 this interaction seems to disappear. The number of articles published in BMGN on themes relating to colonialism declined to less than one per year until 2010. Furthermore, after 1971 as well, a generational

Willem Wertheim, 'De Indonesische samenleving aan de vooravond van de imperialistische expansie: configuraties en stromingen', BMGN 86:1 (1971) 21-25. DOI: https://doi.org/10.18352/bmgnIchr.1643; Jan Pluvier, 'Internationale aspekten van de Nederlandse expansie', BMGN 86:1 (1971) 26-31. DOI: https://doi.org/10.18352/bmgn-lchr.1644.

7 Think, for example, of 'A New Dutch Imperial History' (BMGN - LCHR 128:1, 2012), 'Visions of Dutch Empire' (BMGN - LCHR 132:2, 2017), 'The Dutch East Indies and Europe, ca. 1800-1930' 
shift created a gap in the historiographic connections between Dutch and Indonesian scholars. This was noticed in Jurrien van Goor's 1982 review essay on the bibliographic publication A Critical Survey of Studies on Dutch Colonial History. Van Goor highlighted all the relevant Indonesian and other international publications that had been overlooked by the editors Willem Coolhaas and Gerrit Schutte. His review essay thus reads as a necessary addendum, in which he introduces Indonesian historians and briefly indicates their research fields, starting with the Sejarah Indonesia book series edited by Sartono Kartodirdjo, Djoened Poesponegoro and Nugroho Notosusanto. He also included then-leading historians such as Taufik Abdullah, Soemarsaid Moertono and Adrian Bernard Lapian. ${ }^{10}$ Like these Indonesian historians, Van Goor had been involved in two Dutch-Indonesian historical conferences where the older Indonesian and Dutch historians met the younger generations. ${ }^{11}$

However, Van Goor's call for historical debate with Indonesian historians did not resonate in later issues of BMGN. After 1982, Indonesian historians were hardly cited in the footnotes of Dutch authors, except by Pieter Drooglever. ${ }^{12}$ Even Schutte's 1985 article on foreign historians writing about Dutch colonialism in Indonesia mentions no Indonesian authors; apparently they were not 'foreign' in his view. ${ }^{13}$ Moreover, it seems that geschiedenis', BMGN 97:1 (1982) 53-56. DOI: https://doi.org/10.18352/bmgn-Ichr.2290; Willem Coolhaas and Gerrit Schutte (eds.), A Critical Survey of Studies on Dutch Colonial History (The Hague 1980).

treaty between Indonesia and the Netherlands, the first conference was organised in

Noordwijkerhout, followed in 1978 by the second in Ujung Pandang (Makassar), see Klaas Stutje, Een historische ontmoeting nader beschouwd. Een analyse van de eerste Nederlands-Indonesische historische conferentie in Noordwijkerhout in 1976. Tutorial 3-De Indonesische historiografie (Unpublished student paper; University of Amsterdam, 2009). Senior scholars such as Adrian B. Lapian, Simon L. van der Wal, Sartono Kartodirdjo, Piet Creutzberg, Mattulada and Henri Baudet met young upcoming men such as Taufik Abdullah, Jurrien van Goor, Harsja Bachtiar, Pieter Drooglever and Cees Fasseur (apparently no women were invited). It was in the same spirit that twenty years later Leonard Blussé, with colleagues in Asia and the Netherlands, initiated a series of multilateral research- and educational programs: first in 2000 under the acronym of TANAP (towards a new age of partnership) and after 2006 under the title of ENCOMPASS (encountering a common past in Asia). In the past decade the initiative continued as Cosmopolis program. See also: Jos Gommans, 'Rethinking the voc: Two Cheers for Progress', BMGN - LCHR 134:2 (2019) 142-152. DOI: https://doi.org/10.18352/ bmgn-lchr.10685. Pieter Drooglever, 'De Indonesische kwestie tussen persbericht en egotrip', BMGN 109:1 (1994) 1-16. DOI: https://doi.org/10.18352/bmgn-lchr.3773; Pieter Drooglever, 'Dekolonisatie in twintig delen. Een persoonlijke impressie', BMGN 111:4 (1996) 464-472. DOI: https://doi.org/10.18352/ bmgn-Ichr.4339; Pieter Drooglever, 'Een paar bedenkingen. Discussie over Een daad van vrije keuze', BMGN/LCHR 122:1 (2007) 91-104. DOI: https://doi.org/10.18352/bmgn-lchr.6534.

13 Gerrit J. Schutte, 'De exemplarische Droogstoppel. Een eeuw buitenlandse stemmen over het Nederlandse koloniale beleid', 
The Siauw Giap remained the only author of Indonesian descent who had published in BMGN, until in 2018 Ajeng Ayu Arainikasih, a PhD candidate at Leiden University, and Hafnidar of the University of Muhammadiyah Aceh co-authored an article about the Aceh Museum. ${ }^{14}$

Does this imply that, apart from the Dutch-Indonesian historical conferences of 1976 and 1978, the first generation of historians after Indonesian independence did not read each other's work and did not debate the subjects covered? One of the younger historians of the conferences at Noordwijkerhout and Ujung Pandang (Makassar), Cees Fasseur, was a member of the BMGN editorial board between 1987 and 1993. Apparently he did not conceive of the journal as a possible forum for Indonesian author- or readership. Elsbeth Locher-Scholten, a member of the editorial board between 1994 and 1998, focused almost exclusively on Dutch historians as well. But most of all, her articles stand out because of the close connection to concerns, feelings and traumas within the Indies community of the Netherlands: another generational issue that was inherent in the personal histories of many of the older generation before her. In 1999 she addressed this as a historiographic theme. ${ }^{15}$

In this respect, Locher-Scholten was a pioneer in BMGN. Two years later, Wim van den Doel criticised the historical dimension of such feelings of victimhood regarding the past. At best, he thought, historians would be inconvenient participants ('lastige participanten') in a debate dominated by selfproclaimed spokespersons and organisations of victims, to whom the authorities responded with gestures in the form of monuments, museums or historical research. In his view, historical research was not helpful in this dynamic, since individual memories and collective oral traditions are more powerful than nuanced historical research. ${ }^{16}$ He wrote this in 2001; a decade later, Guno Jones would turn the perspective upside down and explain how historiography cannot be separated from the exercise of power, and how historical narratives emerge from situated knowledge and location-specific perspectives. ${ }^{17}$

BMGN 100:4 (1985) 663-684. DoI: https://doi. org/10.18352/bmgn-Ichr.2661. the Aceh Museum. Objects, Histories and their Narratives', BMGN - LCHR 133:2 (2018) 105-120. DOI: https://doi.org/10.18352/bmgn-lchr.10554. tot Indisch monument: vijftig jaar Nederlandse herinnering aan de Tweede Wereldoorlog in Azië', BMGN 114:2 (1999) 192-222. DoI: https://doi. org/10.18352/bmgn-Ichr.4948.

'Wetenschappelijk onderzoek als Gebaar helpt al helemaal niet. Individuele herinneringen of collectieve overleveringen zijn nu eenmaal sterker dan genuanceerde historische inzichten. De overheid lijkt overigens op haar beurt meer geïnteresseerd in het gebaar van het initiëren van historisch onderzoek, dan in de uitkomsten ervan', Wim van den Doel, 'De stijl van de historicus', BMGN 116:3 (2001) 334-337, 336. DOI: https://doi.org/10.18352/bmgn-lchr.5502.

17 Guno Jones, 'De Slavernij is onze geschiedenis (niet). Over de discursieve strijd om de betekenis van de NTR-televisieserie De Slavernij', BMGN - LCHR 127:4 (2012) 56-82. DOI: https://doi. org/10.18352/bmgn-Ichr.8227. 


\section{Low Countries: a historiographic niche?}

Looking at BMGN alone, we can conclude that before 2010 it hardly served as a platform for discussion on the colonial past. Other journals ${ }^{18}$ should be evaluated as well before arriving at firm conclusions about a lack of transnational exchange between scholars. However, what we can say is that none of the leading Indonesian historians in the 1970 and later ever published in BMGN and they were and are hardly referenced by Dutch authors. It suggests that the generation of historians who did publish in BMGN between 1980 and 2010 mainly focused on Dutch historiographic discourse. ${ }^{19}$ Meanwhile since the 1970 s there had been massive projects in the Netherlands to select and publish primary sources with respect to colonialism (including voc archives) and the decolonisation period. ${ }^{20}$ Apparently, as far as BMGN is concerned, these efforts did not, or could not, result in an active debate among the historians in the two countries: not among those who had lived through the first decades after independence, nor among the younger generation for whom that was history as well. This changed after 2010.

A similar development can be observed in regard to Belgium and the colonial history of the Congo region. BMGN was not a major publishing venue for the extensive research on Belgian colonialism that has appeared over the last twenty years in articles and book reviews. Our quick scan of the fourteen articles relating to the colonial history of the Congo suggests that authors deliberately chose topics that they thought Dutch BMGN readers would be interested in. For instance, in many cases articles include a comparative colonial perspective between the Netherlands Indies and the Belgian-Congo ${ }^{21}$ or between the Southern Netherlands and Spain in the Caribbean. ${ }^{22}$ One article discusses Belgian views on Dutch violence in the decolonisation of Economic and Social History, Tijdschrift voor Geschiedenis and probably most of all Bijdragen tot de Taal-, Land- en Volkenkunde/Journal of the Humanities and Social Sciences of Southeast Asia (BKI), Wacana and Lembaran Sejarah. Important in this respect is the intervention by Schulte Nordholt, Purwanto and Saptari who plea for 'a new perspective', Henk Schulte Nordholt, Bambang Purwanto and Ratna Saptari, Perspektif baru penulisan sejarah Indonesia (Jakarta 2008). Language barriers may also have been a factor in the gap between the two historiographic traditions.
20 In particular: Simon L. van der Wal and Mieke J.B. Schouten, Officiële Bescheiden Betreffende de Nederlands-Indonesische Betrekkingen 1945-1950 (The Hague 1981-1989, four parts).

21 Bertus W. Schaper, 'Nieuwe opvattingen over het moderne imperialisme', BMGN 86:1 (1971) 4-20. DOI: https://doi.org/10.18352/bmgn-lchr.1642; Michel Dumoulin, 'Historiens étrangers et historiographie de l'expansion belge aux XIXe et XXe siècles', BMGN 100:4 (1985) 685-699. DOI: https://doi.org/10.18352/bmgn-lchr.2662. Eddy Stols, 'De Zuidelijke Nederlanden en de oprichting van de Oost- en Westindische Compagnieën', BMGN 88:1 (1973) 1-18. DOI: https:// doi.org/10.18352/bmgn-Ichr.1742. 
conflict with Indonesia between 1945 and $1959^{23}$; another compares the dealing with the colonial past in the Belgian and Dutch public sphere ${ }^{24}$ or includes Belgian/Congolese and Dutch/Indonesian histories in a discussion on colonial violence. ${ }^{25}$ Those articles that focus on Belgian colonial history alone are situated within a broader theme such as medical history or material culture. ${ }^{26}$ Ten of the fourteen articles between 1971 and 2020 were published after 2006: four appeared in a themed issue on the Belgian-Congolese past in relation to the death of Patrice Lumumba (2007), and four others, including a book review, appeared in various issues in 2020. ${ }^{27}$

The small number of articles since 2007 focusing on Belgian (and Dutch) historiographic debates suggest a similar trend we observed in regard to publications on Dutch colonialism. Idesbald Goddeeris (one of BMGN's editors since 2019) and Sindani Kiangu opened up this 'niche'-focus in their extensive review article from 2011, published a year after the fiftieth anniversary of Congolese independence. They discussed a wide range of international publications on Belgian colonialism and focused in particular on Congolese and Belgian authors and perspectives. ${ }^{28}$

Historiographic isolation, however, has remained very present with respect to the colonial history of the Antilles. We sadly conclude that, except for one extensive review article by Peter $\mathrm{Meel}^{29}$, the comparative article by

Belgium and the Netherlands', BMGN - LCHR 135:1 (2020) 70-94. DOI: https://doi.org/10.18352/bmgnIchr.10783.

25 Thijs Brocades Zaalberg and Bart Luttikhuis, 'Extreem geweld tijdens dekolonisatieoorlogen in vergelijkend perspectief, 1945-1962', BMGN - LCHR 135:2 (2020) 34-51. DOI: https://doi.org/10.18352/ bmgn-Ichr.10813.

themed issue by Cambodian author Sokhieng

Au, 'Medical Orders: Catholic and Protestant

Missionary Medicine in the Belgian Congo 1880-1940', BMGN - LCHR 132:1 (2017), 62-82. DOI: https://doi.org/10.18352/bmgn-lchr.10309; and the contribution to the forum discussion on 'Decolonisation and colonial collections: An unresolved conflict' by Maarten Couttenier:
'EO.0.0.7943', BMGN - LCHR 133:2 (2018) 91-104. DOI: https://doi.org/10.18352/bmgn-lchr.10553.

27 BMGN/LCHR 122:3 (2007), with contributions by Emmanuel Gerard, Georgi Verbeeck, Christ Klep and Bambi Ceuppens; Benoît Henriet, 'Reuben A. Loffman, Church, State and Colonialism in Southeastern Congo, 1890-1962. Cambridge Imperial and Post-Colonial Studies Series', BMGN - LCHR 135:2 (2020). DOI: http://doi. org/10.18352/bmgn-Ichr.10855.

28 Idesbald Goddeeris and Sindani E. Kiangu, 'Congomania in Academia. Recent Historical Research on the Belgian Colonial Past', BMGN/LCHR 126:4 (2011) 54-74. DOI: https://doi.org/10.18352/ bmgn-Ichr.7442.

29 Meel discusses Gert Oostindie and Inge Klinkers, Knellende Koninkrijksbanden. Het Nederlandse dekolonisatiebeleid in de Caraiben, 1940-2000, I, 1940-1954, II, 1954-1975, III, 1975-2000 (Amsterdam 2001) in a review article on Suriname: Peter Meel, 'Dimensies van onafhankelijkheid: de Surinaamse ervaring', BMGN 117:2 (2002) 185-203. DOI: https:// doi.org/10.18352/bmgn-Ichr.5656. 
Eddy Stols on the history of the Southern Netherlands and Spain in the Caribbean ${ }^{30}$ and, finally, one article on the Dutch Atlantic by Gert Oostindie ${ }^{31}$, no other article deals with histories of the former Netherlands Antilles, or one of its islands specifically. A search with various keywords provided only five hits where the Netherlands Antilles were mentioned in passing, mostly leading to phrases ending with '[...] Suriname and the Antilles'. In other settings, Oostindie has warned that whereas these Caribbean islands are part of the Kingdom of the Netherlands, their histories are hardly known in the Netherlands, and very few Dutch historians work in these fields and with Caribbean colleagues. BMGN confirms this trend. ${ }^{32}$

The same is true for the history of Suriname. Except for one article in 1994 and the review article by Peter $\mathrm{Meel}^{33}$, Suriname was mentioned only in passing over the last fifty years, until in 2013 Karwan Fatah-Black wrote about aspects of slavery history. ${ }^{34}$ Around 1975 , the year of Surinamese independence, no article about Suriname was published. ${ }^{35}$ We are also well aware that other journals offered effective platforms for what is called Surinamistiek, Suriname Studies. ${ }^{36}$ However, while Surinamese historians in the past ten years have organised major international historical conferences in Paramaribo attended by many Dutch historians, their outcomes did not resonate in BMGN. ${ }^{37}$ nationalisme. Het dekolonisatievraagstuk in de Surinaamse politiek', BMGN 109:4 (1994), 638-659. DOI: https://doi.org/10.18352/bmgn-Ichr.3920; Idem, 'Dimensies van onafhankelijkheid: de
Surinaamse ervaring', BMGN 117:2 (2002) 185-203. DOI: https://doi.org/10.18352/bmgn-lchr.5656. Tropics: The Limitations of Empire-Centred Approaches to the Early Modern Atlantic World', BMGN - LCHR 128:1 (2013) 31-52. DOI: https://doi. org/10.18352/bmgn-Ichr.8354. In 1974, OSGN (The Organisation of History Students in the Netherlands) organised a threeday conference on the history of Suriname between 1674 and 1974. Of the authors/speakers, only Piet Emmer would publish one (review) article in BMGN: Piet C. Emmer, 'Eender of anders? Nieuwe literatuur over de geschiedenis van de Nederlandse Cariben', BMGN 102:4 (1987) 624-630. DOI: https://doi.org/10.18352/bmgn-lchr.2858. Examples are Oso, Itinerario, The Low Countries Journal of Economic and Social History and NWIG.

37 Maurits S. Hassankhan, Jerry L. Egger and Eric R. Jagdew (eds.), Explorations in the Historiography of Suriname. From Colonial History to History of the People, Volumes 1 and 2 (Paramaribo 2013). 


\section{Decolonisation, de-imperialisation and their historical representations}

In the last ten years, BMGN has published extensively on themes of decolonisation and de-imperialisation. With these terms we mean historiography that critically examines the former colony's process of gaining independence from its European patron. In these articles, authors explore different dimensions, for example of people who were ruled by colonialism and those who ruled, and they also question the legacy that still lingered on after colonial polities ended. BMGN furthermore published articles that examine colonial modernisation, for example Andreas Weber's contribution on the development of natural science ${ }^{38}$, and hence provided an important basis for a reflection on decoloniality. Clearly, BMGN has benefited from the engagement of a broad range of authors, showing that in the Netherlands and Belgium the field has opened up considerably, with an influx of young historians from various universities and institutes, and scholars with very different historical training: from global and regional history, to labour and gender studies, to museum and memory studies, to military and political history. ${ }^{39}$ The last ten volumes of BMGN consist of 305 articles, out of which we find nineteen contributions on decolonisation, twelve on deimperialisation, and ten on hybrid representation.

In the articles on decolonisation, authors examine the process of the re-signification of colonial objects and archives that took place in the former metropoles and analyse activities through the lens of the former colonies. Authors writing about decolonisation wars and violence, such as in the BMGN forum on this topic introduced by Thijs Brocades Zaalberg and Bart Luttikhuis, take a comparative approach, and pay attention to the side of those who fought against colonial rule, such as in Indonesia ${ }^{40}$, Algeria ${ }^{41}$, French Indochina, British Malaysia and Madagascar. ${ }^{42}$ Historians also examine and

European Naturalists and the Netherlands Indies in the Early Nineteenth Century', BMGN - LCHR 134:3 (2019) 72-95, especially 79. DOI: https://doi. org/10.18352/bmgn-Ichr.10741.

See BMGN issues 125:1 (2010) to 135:3/4 (2020).

Thijs Brocades Zaalberg and Bart Luttikhuis,
'Extreem geweld tijdens dekolonisatieoorlogen in vergelijkend perspectief, 1945-1962', BMGN - LCHR 135:2 (2020) 34-51. DOI: https://doi.org/10.18352/ bmgn-lchr.10813; Bart Luttikhuis, 'Juridisch afgedwongen excuses. Rawagedeh, ZuidCelebes en de Nederlandse terughoudendheid', BMGN - LCHR 129:4 (2014) 92-105. DOI: https://doi. org/10.18352/bmgn-Ichr.9863; Azarja Harmanny and Brian McAlisster Linn, “"Technisch Geweld” in de Nederlands-Indonesische Oorlog. Zware

wapens in de periode van dekolonisatie', BMGN - LCHR 135:2 (2020) 93-110. DOI: https://doi. org/10.18352/bmgn-Ichr.10815.

41 Stef Scagliola and Natalya Vince, 'Verkrachting tijdens de Indonesische en Algerijnse onafhankelijkheidsoorlogen. Motieven, contexten en politiek', BMGN - LCHR 132:2 (2020) 72-92. DOI: https://doi.org/10.18352/bmgn-lchr.10818.

42 Roel Frakking and Martin Thomas, 'Indrukken van de microdynamiek van revolutionair en contrarevolutionair geweld. Bewijs van laatkoloniaal Zuidoost-Azië en Afrika vergeleken', BMGN - LCHR 135:2 (2020) 111-131. DOI: https://doi. org/10.18352/bmgn-Ichr.10817. 
compare the fate of the imperial rulers at the end of the Second World War, such as the Netherlands, France and Great Britain. ${ }^{43}$

Decolonisation also explores the ways in which the re-signification of objects, sources and activities of the former colonies takes place in postcolonial times. An article by Ajeng Ayu Arainikasih and Hafnidar that analyses the collections of the Aceh Museum proposes decolonisation as 'featuring narratives [of colonial objects] from the local perspective' to contest the colonial narratives that still prevail. ${ }^{44}$ The attempt from the Indonesian side to reclaim cultural objects that were taken to the Netherlands during the colonial time is an ongoing issue in the decolonisation debate. ${ }^{45} \mathrm{At}$ this point the idea that decolonisation of cultural objects means merely returning the objects to former colonies is contested. For the disputed cultural objects to be decolonised, 'former colonialized peoples have to recover [themselves], to claim a space in which to develop a sense of authentic humanity' because 'part of decolonization concerns our mindset'. ${ }^{46}$ On the other hand, some BMGN authors as Bart Luttikhuis, Christiaan Harinck and Manjusha Kuruppath argue that not only the former colonised but also former colonisers need to move away from a colonial perspective when dealing with the colonial pastfor example, by making a balanced use of sources. ${ }^{47}$ In this regard, the socalled 'archives' can be understood as an institution and a metaphor. ${ }^{48}$

The articles in BMGN that deal with the theme of de-imperialisation explore how the former colonial rulers reappraised the past and attempted to evaluate a prevailing imperial self-perspective in the post-colonial context. The focus of these articles is the former mother countries. In general, imperial history examines 'how the ideas of greatness, reason of state and state

Geen Onderzoek”. Hoe schandalen over koloniaal geweld in de Britse en Nederlandse politiek onschadelijk gemaakt konden worden (1945-1960)', BMGN - LCHR 135:2 (2020) 52-71. DOI: https://doi.org/10.18352/bmgn-Ichr.10816.

Agents of Action: Indonesia's Claimed Cultural

Objects and Decolonization, 1947-1978', BMGN - LCHR 133:2 (2018) 91-104. DOI: https://doi. org/10.18352/bmgn-lchr.10552. van Beurden, 'Decolonization and Colonial Collections: An Unresolved Conflict', BMGN -
LCHR 133:2 (2018) 66-78, especially 67. DOI: https:// doi.org/10.18352/bmgn-Ichr.10551.

47 Bart Luttikhuis and Christiaan H.C. Harinck, 'Voorbij het koloniale perspectief: Indonesische bronnen en het onderzoek naar de oorlog in Indonesië, 1945-1949', BMGN - LCHR 132:2 (2017) 5176, especially 51-55. DOI: https://doi.org/10.18352/ bmgn-Ichr.10340; Manjusha Kuruppath, 'In the Company of Global History', BMGN - LCHR 134:2 (2019) 103-114. DOI: https://doi.org/10.18352/ bmgn-lchr.10688.

48 Michael Karabinos, 'Decolonization in Dutch Archives: Defining and Debating', BMGN - LCHR 134:2 (2019) 129-141, especially 131. DOI: https://doi. org/10.18352/bmgn-Ichr.10687. 
formation were employed' by a metropole (European) country in the creation of a global network of economic and political dominations over the colonies. ${ }^{49}$ De-imperialised history aims to deconstruct such ideas by questioning their tenets. As Alicia Schrikker, BMGN-editor since 2016, asserted in a forum on Dutch imperial history, the first question is whether a long-term analysis would affect the study of the colonial mentality of the national culture of the former metropoles. ${ }^{50}$ For some historians such as René Koekkoek, AnneIsabelle Richard and Arthur Weststeijn, a long-term perspective enables them to examine 'the ideological origins of empire, the historical roots of imperial thoughts and the variety of imperial ideology'. This theme of deimperialisation aims to balance imperial historiography. ${ }^{51}$

However, other authors - among whom two of the authors of this contribution - argue that such a long-term perspective cannot yet overcome fundamental problems of imperial historiography. ${ }^{52}$ One of those structural issues, which our review confirms, is that 'the history of the [...] colonies and that of the metropoles [...] became completely detached from each other'. ${ }^{53}$ For other authors as Remco Raben, de-imperialisation thus means to understand the connectivity of the centres in a web-like manner, without prioritising one centre over the other. ${ }^{54}$

The third category of articles, which emphasise a mutual existence of both communities and material objects of the colonial past, shows a postcolonial hybrid identity as a result of an intermingled relationship between the European and the colonial societies. Some articles in BMGN suggest the integration of colonial identities and the birth of a post-colonial identity, which carries important legacies up to today. ${ }^{55}$ For example, according to

Intellectual History', BMGN - LCHR 132:2 (2017)

97-109, especially 97. DOI: https://doi.org/10.18352/

bmgn-Ichr.10343

50 Alicia Schrikker, 'Visions of Dutch Empire Introduction', BMGN - LCHR 132:2 (2017) 77-78, especially 77. DOI: https://doi.org/10.18352/bmgnIchr.10341.

51 René Koekkoek, Anne-Isabelle Richard and Arthur Weststeijn, 'Vision of Dutch Empire: Towards a Long-Term Global Perspective', BMGN - LCHR 132:2 (2017) 79-96, especially 80-81. DOI: https://doi. org/10.18352/bmgn-Ichr.10342.

52 See Susan Legêne, 'The European Character of the Intellectual History of Dutch Empire', BMGN - LCHR 132:2 (2017) 110-120. DOI: https:// doi.org/10.18352/bmgn-Ichr.10344; Alicia Schrikker, 'Rethinking the voc: Between
Archival Management and Research Practice. Introduction', BMGN - LCHR 134:2 (2019) 96-102. DOI: https://doi.org/10.18352/bmgn-Ichr.10686.

53 Marieke Bloembergen and Vincent Kuitenbrouwer, 'A New Dutch Imperial History: Connecting Dutch and Overseas Past', BMGN LCHR 128:1 (2013) 1-4, especially 1. DOI: https://doi. org/10.18352/bmgn-Ichr.8352.

54 Remco Raben, 'A New Dutch Imperial History? Perambulations in a Prospective Field', BMGN LCHR 128:1 (2013) 5-30, especially 11. DOI: https:// doi.org/10.18352/bmgn-lchr.8353.

55 See, respectively, Klaas Stutje, 'Indonesian Identities Abroad: International Engagement of Colonial Students in the Netherlands, 1908-1931', BMGN - LCHR 128:1 (2013) 151-172. DOI: https:// doi.org/10.18352/bmgn-lchr.8359; and Caroline Drieënhuizen, 'Being "European” in Colonial 
an Nwo-funded research project 'Bringing History Home: Postcolonial Identity Politics in the Netherlands', the wave of immigrants from the former colonies to Europe has created a 'market of cultural identities' in the postcolonial Netherlands and has raised the potential to expand the roots of identity politics. ${ }^{56}$ The post-colonial adoption of children from Rwanda and Burundi in Belgian families also reflects a continuation of the child separation practices of the colonial time, although the aim of the adoption is to safeguard the children from the uncertain political and economic situation of their homeland. ${ }^{57}$

Indeed, in the post-colonial time, Europe has been shaken by the question of identity in regard to the large numbers of immigrants from the former colonies. This has created a problem of historical representation. The controversies that arose with the founding of the European Parliament's House of European History (HEH) in Brussels show how problematic it is to provide a single representation of European history. While Europe has been 'united' by an umbrella institution in the form of the European Union, its representation in the HEH cannot just include the society of Europe now and then. Europe's past should unarguably include its (past) connection with the colonies. 'European histories' instead of 'European history' should be used for a post-colonial representation of identities to be inclusive. ${ }^{58}$

\section{Conclusion}

In 1971 the historian Bertus Schaper concluded his contribution with the following reflection:

In order to free oneself from this imperialistic virus, all peoples, former imperial rulers as well as former colonised, will have to make themselves aware of their hereditary burden. The only way this is possible is through analysing their imperial and colonial past. Such an analysis is one of the functions of history. Also for the Dutch, who are inclined to a certain naivety in both a pragmatic and

Indonesia. Collectors and Collections between

Yogyakarta, Berlin, Dresden and Vienna in the Late Nineteenth Century', BMGN - LCHR 134:3 (2019) 2146. DoI: https://doi.org/10.18352/bmgn-lchr.10739.

Immigrants and the Dutch Cultural Arena', BMGN/ LCHR 126:2 (2011) 54-70, especially 59-65. DOI: https://doi.org/10.18352/bmgn-lchr.7310.

57 Chiara Candaele, 'Mother Metropole: Adoptions of Rwandan Minors in Postcolonial Belgium (19701994)', BMGN - LCHR 135:3/4 (2020) 209-233. DOI: https://doi.org/10.18352/bmgn-lchr.10879.

58 Elizabeth Buettner, 'What - and who - is "European" in the Postcolonial EU? Inclusions and Exclusions in the European Parliament's House of European History', BMGN - LCHR 133:4 (2018) 132148. DOI: https://doi.org/10.18352/bmgn-Ichr.10615. 
dogmatic sense, such a historical self-examination, which certainly does not need to deteriorate into self-accusations or masochism, can have a liberating effect. 59

Our analysis of the articles published in BMGN in the subsequent 49 years shows that the realisation of Schaper's proposal proceeded in fits and starts. The relationship with the colonial past of the different generations of scholars who published in BMGN changed over time. Belgian colonial history was absent in most of the volumes, as was the history of Dutch colonialism in the Caribbean and Suriname. BMGN also reflects little of the ongoing cooperation between Indonesia and the Netherlands, or any of the other former colonies for that matter. Old questions about the character of Dutch imperialism continued to haunt the subsequent generations. At present societal and academic debates centre on themes such as colonial violence during the wars of independence, restitution of colonial objects, legacies of slavery, and political responsibility for past injustices. The process that Schaper forecast has accelerated over the past ten years, but with a diversification of themes, sources, methods and perspectives, which probably go beyond what he had in mind at the time. In our capacity as authors, editors and reviewers, we realise that we have played a role in this, of course, and it is up to a next generation of scholars to review these developments from a greater temporal distance. ${ }^{60}$

When looked at from the perspective of Indonesia, the articles provide analyses that are useful for academic readers from the former colonies to understand how the colonial past has been reconstructed in the contemporary scholarship of the former metropoles. ${ }^{61}$ Many of the recent articles represent a paradigm shift aimed to revisit colonial and imperial historiography. Unfortunately, a parallel picture about what has happened in the academic world of the former colonies has been relatively absent from the journal. bevrijden zullen de volken, ex-imperiale zowel als ex-koloniale, zich van hun erfelijke belastheid bewust moeten maken. Dat is slechts mogelijk door de analyse van hun imperiale en koloniale verleden. Zulk een analyse behoort tot de functies van de geschiedenis. Ook voor het Nederlandse volk dat zowel in pragmatische als dogmatische zin tot een zekere naïveteit geneigd is, zal zulk een historisch zelfonderzoek dat bepaald niet in zelfbeschuldigingen of masochisme behoeft te ontaarden, een bevrijdende werking kunnen hebben'. Cited from Bertus W. Schaper, 'Nieuwe opvattingen over het moderne imperialisme', BMGN 86:1 (1971) 4-20.

\footnotetext{
DOI: https://doi.org/10.18352/bmgn-lchr.1642. Translation by authors.

6o Apart from our authorship we may mention that Susan Legêne was chair of the KNHG between 2011 and 2019, Alicia Schrikker has been an editor of BMGN since 2016, and Agus Suwignyo has been involved as an article reviewer.

61 Some articles published in BMGN - LCHR, for example in the issues of BMGN - LCHR 128:1 (2013), 132:4 (2017), and 133:3 (2018), have become important reading for students on the courses 'Indonesian History of the $19^{\text {th }}$ and $20^{\text {th }}$ Centuries', 'The Modern History of Europe' and 'History and Memory Making' at the Department of History, Universitas Gadjah Mada, Yogyakarta, Indonesia.
} 
Over the past twenty years in Indonesia, public and academic historians have worked on the decolonisation theme beyond the nationalist approach. A history of the Padri War in West Sumatra (1803-1837), for example, has been re-examined not merely as a war against the Dutch, but as one that stemmed from conflicting identity politics between the Muslim Minang and the Christian Batak peoples. ${ }^{62} \mathrm{~A}$ history of the Indonesian political revival of the early twentieth century has been rewritten in the frame of social modernisation, rather than a narrow political history of the nationalist movement only. ${ }^{63}$ The migration of the Javanese people, to cite yet another example, has recently been reappraised in the framework of global migration that begun in the eleventh century, thus reassessing the traditional Europerelated periodisation of migration. ${ }^{64}$

And finally, after the dissolution of the colonial society, the relationship between the former colonial and metropole countries continues within a different political realm. But the renewed relationship has been neglected in the study of decolonisation. It is time for collaboration between scholars of the former colonised and coloniser societies to intensify and to explore the varied dimensions of the pasts with a fresher look.

\footnotetext{
Agus Suwignyo is associate professor at the History Department of Gadjah Mada University in Yogyakarta, Indonesia. He received his PhD from Leiden University in 2012. His research focuses on the social history of Indonesia and Southeast Asia dealing with education, social transformation and the state. His publications include 'Indonesian National History Textbooks after the New Order: What's New under the Sun?', Bijdragen tot de taal-, land- en volkenkunde/ Journal of the Humanities and Social Sciences of Southeast Asia 170:1 (2014) 113-131. DOI: https://doi.org/10.1163/22134379-17001008; 'Gotong royong and social citizenship in Indonesia 1940s-1990s', Journal of Southeast Asian Studies 50:3 (2019) 387-408. DoI: https://doi.org/10.1017/Soo22463419000407; Pendidikan, Kekuasaan dan Kolonialisme (Yogyakarta 2019); and as an editor: Pengetahuan Budaya dalam Khazanah Wabah (Yogyakarta 2020). E-mail: suwignyo_agus@ugm.ac.id.
} Paderi ke Tapanuli: Masalah Fakta dan Fiksi dalam Sejarah Indonesia', in: Muhammad Nursam, Baskara T. Wardaya and Asvi Warman Adam (eds.), Sejarah yang Memihak: Mengenang Sartono Kartodirjo (Yogyakarta 2008) 319-323.

63 See, for example, Said Hamid Hassan, Sri Margana, Bondan Kanumoyoso and Kresno
Brahmantyo, History of Indonesia: A Resource Book (Jakarta 2020), especially 56-68.

64 See, for example, Rosemarijn Hoefte and Peter Meel (eds.), Departing from Java: Javanese Labour, Migration and Diaspora (Copenhagen 2018), especially $4-8$. 
Alicia Schrikker is senior lecturer in colonial and global history at Leiden University and chair of the Vereniging KITLV. She is an expert in the history of colonial societies with a focus on Sri Lanka and Indonesia. Alicia obtained her PhD in 2006 with a thesis on Dutch and British colonialism in Sri Lanka during the age of revolutions. She currently leads two Nwo funded projects on everyday colonialism in the Indian Ocean. Her recent publications deal with socio-legal history, slavery, historic disaster and Dutch colonial culture in the Indian Ocean. Together with Nira Wickramasinghe she recently edited the volume Being a Slave: Histories and Legacies of European Slavery in the Indian Ocean (Leiden 2020), DOI: https://doi.org/10.24415/9789087283445. Alicia was editor and editor-in-chief of the journal Itinerario between 2006 and 2016 and has been editor with BMGN - Low Countries Historical Review since 2016.

E-mail: a.f.schrikker@hum.leidenuniv.nl.

Susan Legêne is professor of political history at the Vrije Universiteit Amsterdam (VUA), and dean of the faculty of Humanities. Her research focuses on culture and power, and the impact of imperialism on state formation and citizenship. While a staff member of the Royal Tropical Institute in Amsterdam, she obtained her PhD in 1998 with a thesis on nineteenth-century colonialism, the formation of the Kingdom of the Netherlands, and the emergence of imperial culture in Europe. Together with Wayne Modest she is leading the international program Pressing Matter - Ownership, value and the question of colonial heritage in museums (2021-2025) funded by the National Science Agenda of the Netherlands. E-mail: s.legene@vu.nl. 